\title{
Preparation of Alumina Fiber-Type Catalyst for Methane Combustion by Sol-Gel Method
}

\author{
Yasuyuki MIZUSHIMA ${ }^{\dagger}$, Masahiro SEKINE ${ }^{\dagger \dagger}$ and Makoto HORI ${ }^{\dagger \dagger}$ \\ Colloid Research Institute, 350-1, Ogura, Yahatahigashi-ku, Kitakyushu-shi 805 \\ ゾルゲル法によるアルミナファイバー型メタン燃焼触媒の調製 \\ 水嶋康之 $\cdot$ 関根正裕㠹 ·堀 誠 ${ }^{\dagger \dagger}$ \\ (株)コロイドリサーチ，805 北九州市八幡東区大字尾倉 350-1
}

[Received February 1, 1993; Accepted June 16, 1993]

\begin{abstract}
Porous alumina fibers were prepared by the sol-gel method, and palladium was supported on the fibers by dipping and mixing methods. In the latter palladium acetate was mixed with a sol before spinning. Better dispersion of palladium particles in the fiber was achieved by the mixing method than by the dipping method. The specific surface area of the fiber-catalyst prepared by the mixing method was one fiftieth smaller than those of the other catalysts. The activity of the fiber-type catalysts for methane combustion was evaluated and compared with that of a commercial granular-type alumina. The fiber-type catalysts showed higher activities than the granular one. Such a high activity of the fiber-type catalyst prepared by the mixing method, despite its small surface area, was attributed to its fibrous form and better dispersion of palladium particles. However, the activity of fiber-type catalysts drastically decreased by firing at $1200^{\circ} \mathrm{C}$ for $5 \mathrm{~h}$.
\end{abstract}

Key-words : Alumina fiber, Methane combustion, Fiber catalyst, Palladium, Porous fiber

\section{Introduction}

Many catalysts have been developed for combustion of liquefied petroleum gas, kerosene or methane. Non-porous inorganic fibers such as asbestos, glass fiber, simple layered mat made of alumina-silica fibers and blanket have been used as a support of catalyst.1),2) Fiber-type catalysts may have the advantage of less internal resistance against gas flow than grain- or pellet-type catalysts.

Platinum has been supported on the outer side of non-porous inorganic fibers as a catalyst, however,

\footnotetext{
$\uparrow$ Now with Komaki Factory, NGK Spark Plug Co., Ltd., 2808, Iwasaki, Komaki-shi, Aichi 485

現在:日本特殊陶業(株)小牧工場中央研究所, 485 愛知県 小牧市大字岩崎 2808

† Now with Plastic Technical Center, Nippon Steel Chemical Co., Ltd., 1618, Ida, Nakahara-ku, Kawasaki-shi 211 現在: 新日鐵化学(株)プラスチック技術センター, 211 川 崎市中原区井田 1618

t† Now with Kurosaki Refractory Co., Ltd., 1-1, Higashihama, Yahata-Nishi-ku, Kitakyushu-shi 806

現在: 黑崎割業(株)技術研究所第三研究室, 807 北九州市 八幡西区東浜町 1-1
}

the catalysts did not show activity enough for obtaining the sufficient rate of combustion of methane and their life time was not long enough.3) Sadamori and Chikazawa reported a porous fiber catalyst, ${ }^{4)}$ using the porous alumina fiber containing $5 \% \mathrm{SiO}_{2}$ (Saffil Alumina Fiber Catalytic Grade, ICI Co., Ltd.) ${ }^{5)}$ as a catalyst support, whose specific surface area is as much as $150 \mathrm{~m}^{2} / \mathrm{g}$. Rhodium and platinum supported fibers were found to show high activity for methane combustion.

One of authors has reported the preparation of the silicon nitride glass fibers by heating porous sol-gelderived silica gel fibers in nitrogen atmosphere. ${ }^{6)}$ In the present work, Authors prepare alumina fibers containing $10 \mathrm{~mol} \%$ silica in the similar manner. Previously, we reported that addition of $10 \mathrm{~mol} \%$ silica to alumina was most effective to obtain high specific surface area at temperatures above $1000^{\circ} \mathrm{C} .{ }^{7)}$ Palladium was selected as a catalyst and supported on the alumina fibers by two ways; one was the mixing method in which palladium acetate was added to the hydrolyzed alumina-silica sol, and the other was the dipping of calcined fibers in palladium acetate solution. Palladium was reported to have higher activity than platinum for methane oxidation, ${ }^{3), 8)}$ and larger heat resistance. ${ }^{9), 10)}$ The activities of these palladium supported fibers are evaluated for methane combustion.

\section{Experimental}

Preparation procedure is shown in Fig. 1. Aluminum sec-butoxide $\left(\mathrm{Al}\left[\mathrm{OCH}\left(\mathrm{CH}_{3}\right) \mathrm{CH}_{2} \mathrm{CH}_{3}\right]_{3} ; \mathrm{Al}\right.$ $\left.\left(\mathrm{OBu}^{\mathrm{sec}}\right)_{3}\right)$ was reacted with triethanol amine (TEA) in 2-butanol ( $\mathrm{Al} / \mathrm{TEA} / 2$-butanol $=3 / 1 / 15)$. Then, tetraethyl orthosilicate (TEOS) was added to the solution $\left(\mathrm{Al}_{2} \mathrm{O}_{3} / \mathrm{SiO}_{2}=90 / 10\right)$. The mixture of alumina-TEA complex and TEOS was hydrolyzed with equimolar amount of water (diluted by 2 butanol) to $\mathrm{Al}\left(\mathrm{OBu}^{\mathrm{sec}}\right)_{3}$ and TEOS, the alumina-silica sol (hereafter, the name 'alumina sol' is used for abbreviation) resulting. Palladium acetate dissolved in acetone was mixed with the alumina sol to support $1 \mathrm{wt} \%$ palladium on the resultant alumina-silica fiber (abbreviated as 'alumina fiber' in the follow- 


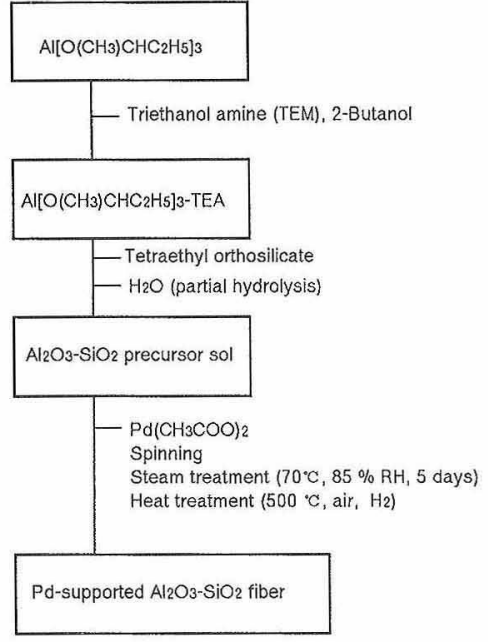

Fig. 1. Flow chart for preparing Pd-supported alumina fibers.

ings). This is named the mixing method. The sol was kept agitated in nitrogen atmosphere to obtain proper viscosity for spinning (300-800 poise). Then, viscous alumina sol was spun into the continuous gel fiber with the spinning apparatus. The gel fibers were aged in a high humidity atmosphere of $85 \% \mathrm{RH}$ at $70^{\circ} \mathrm{C}$ for 5 days to complete the hydrolysis of alkoxide.6) The palladium supported alumina fiber was calcined at $500^{\circ} \mathrm{C}$ for $2 \mathrm{~h}$ in the air, and for $2 \mathrm{~h}$ in the hydrogen atmosphere.

The alumina fiber with catalyst was also prepared by the dipping method as follows. The preparation procedure of alumina fiber is the same as above except for palladium addition. The spun alumina gel fiber was calcined at $1000^{\circ} \mathrm{C}$ for $2 \mathrm{~h}$, followed by dipping into palladium acetate solution to support 1 wt $\%$ palladium on the fiber. The alumina fiber was dipped in a palladium acetate solution with a small amount of hydrochloric acid as a competitive absorbent. The solvent was gradually evaporated to support palladium on the fiber. Then, the palladium supported alumina fiber was calcined at $500^{\circ} \mathrm{C}$ for $2 \mathrm{~h}$ in air, and for $2 \mathrm{~h}$ in the hydrogen atmosphere. A commercial porous granular alumina (CSR-2; Catalyst and Chemicals) was calcined at $1000^{\circ} \mathrm{C}$ for $2 \mathrm{~h}$ and palladium was supported using the dipping method for a comparison.

The fibers were observed using a scanning electron microscopy (SEM; JSM-840, JEOL) and a transmission electron microscopy (TEM ; JEM $2000 \mathrm{EX}, 200 \mathrm{kV}$, JEOL). The specific surface areas of the fibers were measured by the single point BET method using nitrogen as an absorbent. The pore size distribution was measured using a mercury porosimeter (Poresizer; Parametrics). The crystalline phases of the alumina fibers were determined using X-ray diffraction (XRD) technique (RAD-IIC system ; Rigaku Co.).

The activity of the catalysts for methane combustion was measured using a fixed-bed flow reactor.
The $1 \mathrm{~g}$ of each Pd-supported alumina fiber was packed into a quartz tube, then, mixed gas consisting of 1 vol\% of methane and 99 vol\% of air was flowed into the quartz tube at a rate of $1 \mathrm{ml} / \mathrm{min}$. The combustion reaction of methane was induced by heating. Gases evolved through combustion were analyzed by gas chromatography (GC-8A, Shimadzu Co.).

\section{Results and discussion}

The fibers about $20-30 \mu \mathrm{m}$ in diameter were able to be spun continuously. Figure 2 shows the SEM micrograph of the Pd-supported alumina fiber catalyst prepared by the mixing method.

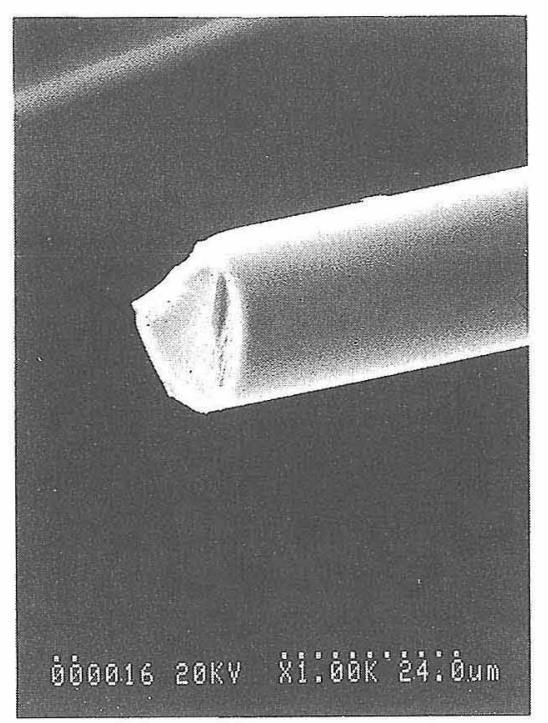

Fig. 2. SEM micrographs of the Pd-supported alumina fiber prepared by the mixing method* (* see text).

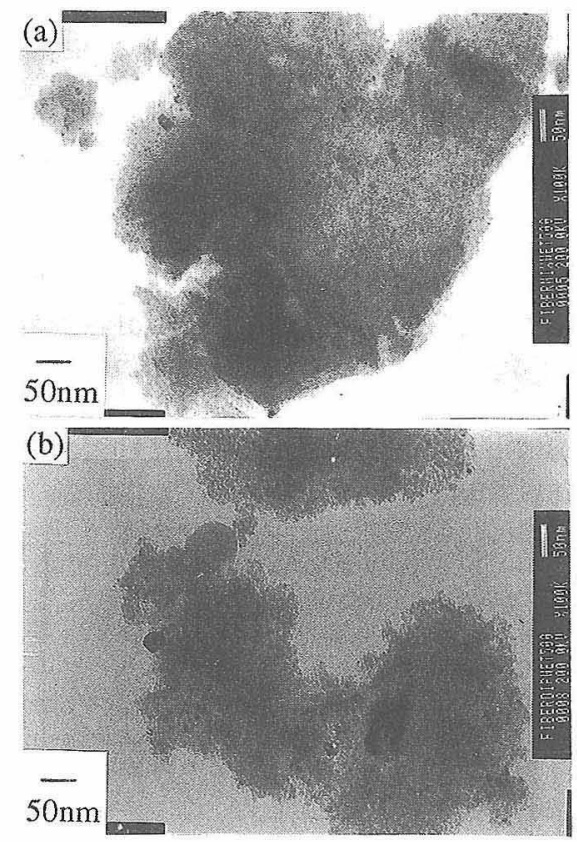

Fig. 3. TEM micrographs of the Pd-supported alumina fibers. Pd was supported by (a) the mixing method*, (b) the dipping method* (* see text). 
Figures 3(a) and (b) show TEM micrographs of the palladium particles dispersed in the alumina fibers prepared by the mixing method (alumina fiber(mixing)) and the dipping method (alumina fiber (dipping)), respectively. Palladium particles in the alumina fiber (mixing) were fine and well dispersed, while very coarse particles were observed in the alumina fiber (dipping).

Figure 4 shows the catalytic activity of the Pd-supported alumina fibers and CSR-2 for methane combustion. The Pd-supported alumina fibers have higher activity than the CSR -2 . The specific surface areas of the fibers and CSR-2 are shown in Table 1. Although the alumina fiber (mixing) has one fiftieth smaller specific surface area than the CSR-2, it has higher activity than the CSR-2. Furthermore, although the present preparation procedure should yield porous alumina fibers as reported, ${ }^{6)}$ the specific surface area of the Pd-supported alumina fiber (mixing) is rather small. In this case, palladium acetate or acetone added to the alumina sol may affect the polycondensation rate or hydrolysis rate of alkoxides, causing a decrease in specific surface area of resultant gels.

Catalysts are required to have high heat-resistance when used in combustion of fuel. They are usually exposed to temperatures higher than $1000^{\circ} \mathrm{C}$. So, the $\mathrm{Pd}$-supported alumina fibers were fired at $1200^{\circ} \mathrm{C}$ for $5 \mathrm{~h}$ and their activity was measured. Figure 5 shows the activity of the Pd-supported alumina fibers and

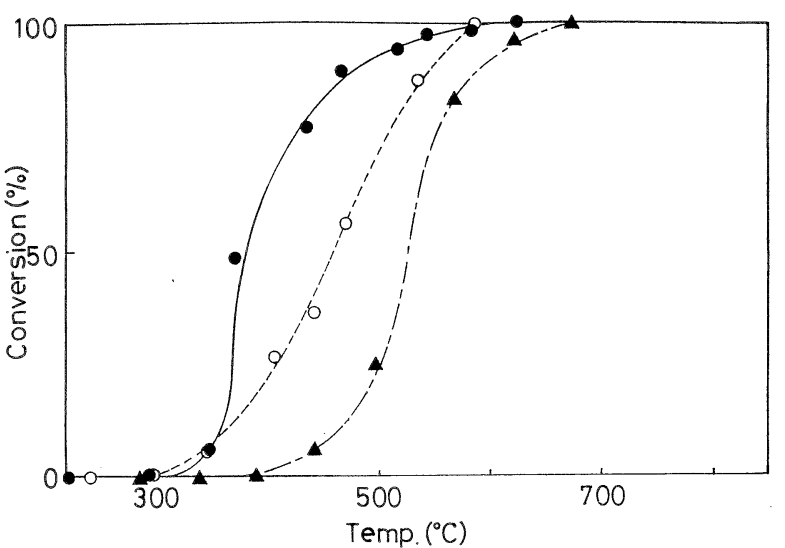

Fig. 4. Catalytic activity of the Pd-supported alumina fibers and CSR-2.

Alumina fiber (mixing),

$\Delta$ CSR-2.

Table 1. Specific surface area (S.S.A.) of the Pd-supported alumina fibers and CSR-2 after firing at $500^{\circ} \mathrm{C}$ for $2 \mathrm{~h}$ in air and $2 \mathrm{~h}$ in hydrogen.

\begin{tabular}{lccc}
\hline & $\begin{array}{c}\text { Alumina fiber } \\
\text { (mixing) }\end{array}$ & $\begin{array}{c}\text { Alumina fiber } \\
\text { (dipping) }\end{array}$ & CSR-2 \\
\hline $\begin{array}{l}\text { S.S.A. } \\
\left(\mathrm{m}^{2} / \mathrm{g}\right)\end{array}$ & 2.62 & 174.3 & 125.0 \\
\hline
\end{tabular}

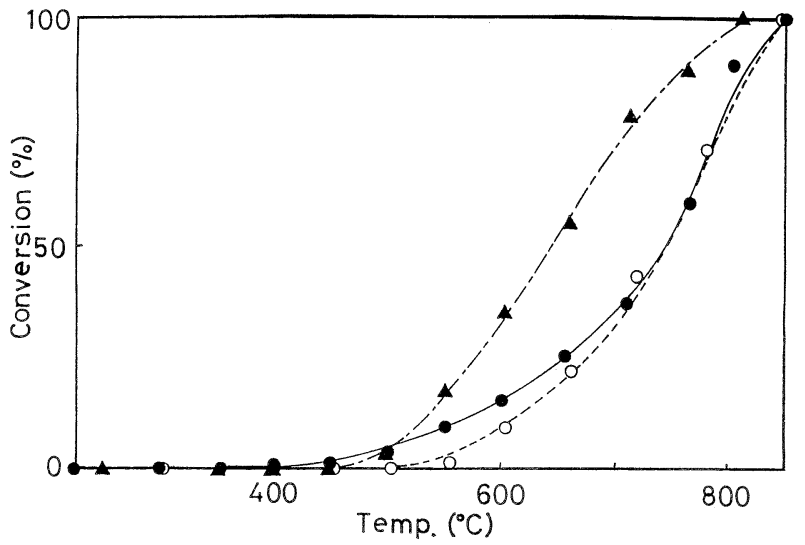

Fig. 5. Catalytic activity of the Pd-supported alumina fibers and CSR-2 after firing at $1200^{\circ} \mathrm{C}$ for $5 \mathrm{~h}$.

Alumina fiber (mixing), Alumina fiber (dipping),

A CSR-2.

Table 2. Specific surface area (S.S.A.) of the Pd-supported alumina fibers and CSR -2 after firing at $1200^{\circ} \mathrm{C}$ for $5 \mathrm{~h}$ in air.

\begin{tabular}{lccc}
\hline & $\begin{array}{c}\text { Alumina fiber } \\
\text { (mixing) }\end{array}$ & $\begin{array}{c}\text { Alumina fiber } \\
\text { (dipping) }\end{array}$ & CSR-2 \\
\hline $\begin{array}{l}\text { S.S.A. } \\
\left(\mathrm{m}^{2} / \mathrm{g}\right)\end{array}$ & 0.95 & 13.8 & 8.1 \\
\hline
\end{tabular}

CSR-2 after firing. The activity of all the catalysts deteriorated. Especially, the alumina fibers drastically lost their activities. Table 2 shows the specific surface area of the $\mathrm{Pd}$-supported alumina fibers and CSR-2 after firing at $1200^{\circ} \mathrm{C}$ for $5 \mathrm{~h}$. The alumina fiber (mixing) showed smaller specific surface area than $1 \mathrm{~m}^{2} / \mathrm{g}$ but the alumina fiber (dipping) still maintained a relatively high specific surface area more than $10 \mathrm{~m}^{2} / \mathrm{g}$. The decrease in the activity of the alumina fiber (mixing) is attributed to the almost complete loss of its specific surface area on sintering. However, the decrease of the activity of the alumina fiber (dipping) can not be attributed merely to the same cause, because the CSR-2 having smaller specific surface area than the alumina fiber (dipping) maintained higher activity.

Figure 6 shows XRD patterns of the Pd-supported alumina fibers and CSR-2 after firing at $1200^{\circ} \mathrm{C}$ for $5 \mathrm{~h}$. The crystalline phase in the alumina fiber (dipping) and CSR-2 is $\alpha$-alumina and that of the alumina fiber (mixing) is $\theta$-alumina. $\operatorname{Pd}(111)$ and (200) diffraction peaks were recognized at $40.0^{\circ}$ and $46.7^{\circ}$ $(2 \theta)$ both in the alumina fiber (dipping) and CSR-2. Namely, the peaks of palladium were hidden in the $\theta$ alumina peaks in the alumina fiber (mixing). The crystalline size of palladium calculated from the half height peak width of the $\operatorname{Pd}(111)$ peaks by Scherrer's equation is $38 \mathrm{~nm}$ in the alumina fiber (dipping) and $80 \mathrm{~nm}$ in the CSR-2.11) The alumina fiber (dipping) has smaller palladium crystals than the CSR-2. This means that dispersion of palladium is 


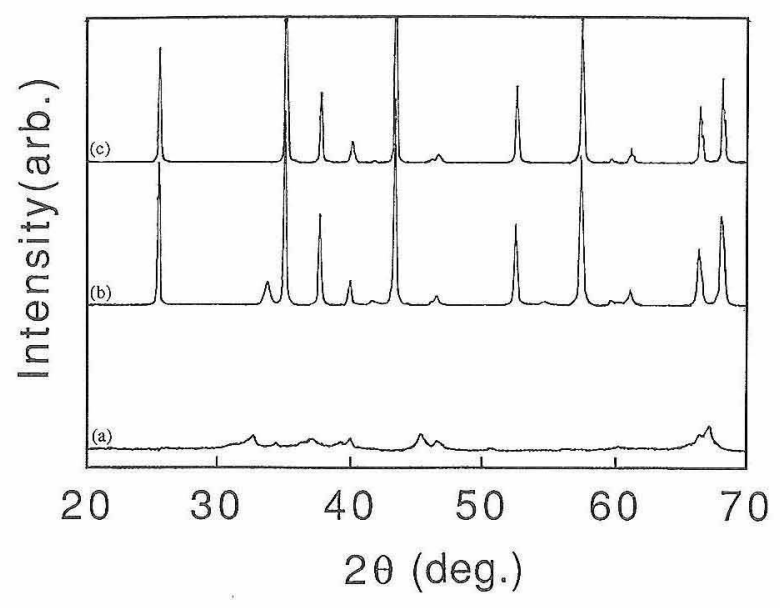

Fig. 6. XRD patterns of the Pd-supported alumina fibers and CSR-2 after firing at $1200^{\circ} \mathrm{C}$ for $5 \mathrm{~h}$.

(a) Alumina fiber (mixing), (b) Alumina fiber (dipping), (c) CSR-2.

better in the alumina fiber (dipping) than in the CSR-2. ${ }^{12)}$ In fact, the initial activity of the Pd-supported alumina fiber (dipping) at $400-500^{\circ} \mathrm{C}$ is almost the same or slightly better than that of the CSR-2.

Figure 7 shows SEM micrographs of the surfaces of the Pd-supported alumina fibers and CSR-2 after firing at $1200^{\circ} \mathrm{C}$ for $5 \mathrm{~h}$. The alumina fiber (dipping) and CSR-2 maintain porous structure. The surface of the alumina fiber (dipping) is smoother than that of the CSR-2, while, pores can not be observed in the alumina fiber (mixing) at all.

Figure 8 shows the pore size distributions of the alumina fiber (dipping) and CSR-2 after firing at $1200^{\circ} \mathrm{C}$ for $5 \mathrm{~h}$. The alumina fiber (dipping) has pores around $40 \mathrm{~nm}$ and also pores smaller than 10 $\mathrm{nm}$. The CSR-2 has pores mainly from $500 \mathrm{~nm}$ to 50 $\mathrm{nm}$. As to the alumina fiber (mixing), pores were not detected at all. The pore volume fraction of the CSR-2 is $55.7 \%$ and that of the alumina fiber (dipping) is only $5.4 \%$. The alumina fiber (dipping) has higher specific surface area but less pore volume fraction than the CSR-2. The low activity of the alumina fiber (dipping) compared to CSR-2 is due to its less pore volume fraction.

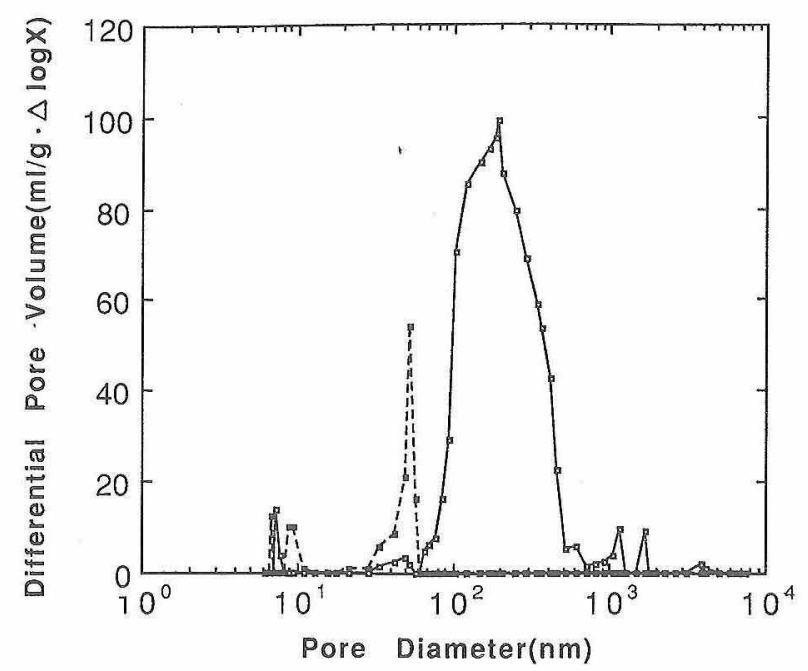

Fig. 8. Pore size distributions the Pd-supported alumina fiber (dipping) and CSR-2 after fring at $1200^{\circ} \mathrm{C}$ for $5 \mathrm{~h}$.

Alumina fiber (dipping), $\square$ CSR-2.

The majority of pores of the CSR-2 is in the so called macro-pore range, and the pores $(40 \mathrm{~nm})$ of the alumina fiber (dipping) is in the meso-pore range. ${ }^{13), 14)}$ In general, molecular diffusion is dominant in the macro-pore range and Knudsen diffusion is dominant in the meso-pore range. Therefore, the pores in the macro-pore range give routes for diffusion of reactant gases and those in the mesopore range do beds for catalyst particles. ${ }^{15)-17)}$ Eventually, the reactant gases are difficult to diffuse in the alumina fibers (dipping) compared with the CSR-2, which may be a major reason that the former has lower activity than the latter.

\section{Conclusions}

(1) Alumina fiber uniformly containing catalyst metal particles is prepared by the sol-gel method.

(2) Pd-supported alumina fibers show higher activity than a $\mathrm{Pd}$-supported alumina grains (CSR-2) for methane combustion, although the alumina fiber (mixing) has one fiftieth smaller specific surface area.

(3) $\quad \mathrm{Pd}$-supported alumina fibers fired at $1200^{\circ} \mathrm{C}$ for $5 \mathrm{~h}$ show less activity than the Pd-supported
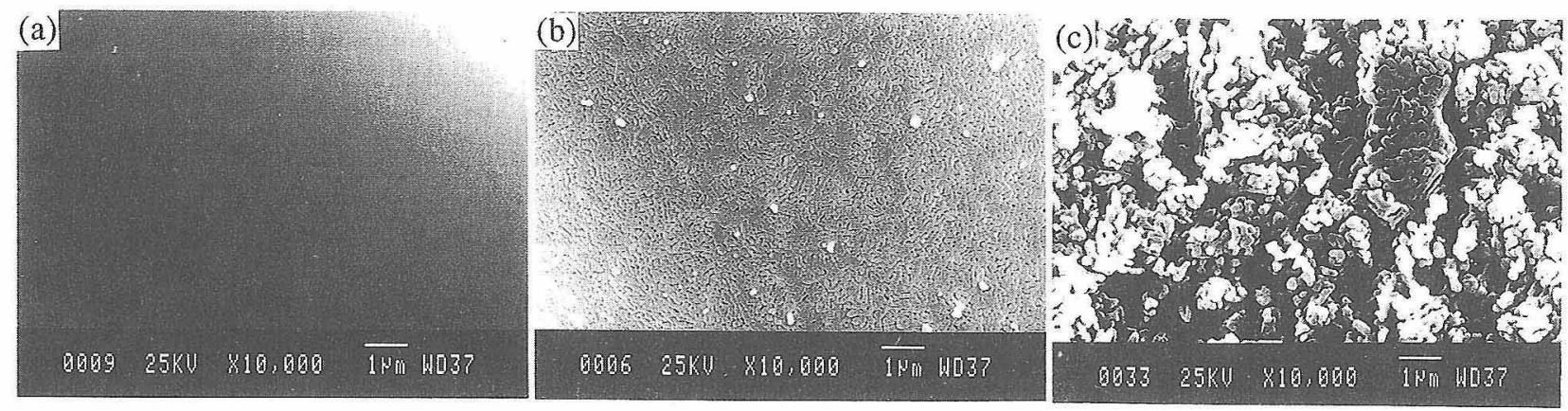

Fig. 7. SEM micrographs of the surface the Pd-supported alumina fibers and CSR-2 after firing at $1200^{\circ} \mathrm{C}$ for $5 \mathrm{~h}$. (a) Alumina fiber (mixing), (b) Alumina fiber (dipping), (c) CSR-2. 
CSR-2. This is explained by the facts that on sintering, the alumina fiber (mixing) loses the specific surface area completely, and the alumina fiber (dipping) maintains the relatively large specific surface area but loses pore volume fraction differing from the CSR-2.

Acknowledgement The authors would like to thank Mr. Noguchi for the assistance of preparing fibers.

\section{References}

1) S. W. Radcliffe and R. G. Hickman, J. Inst. Fuel, (Dec.) , 208 (1975).

2) S. Sicardi and A. Giannetto, L. Riv. d. Com., 31, 321 (1977).

3) R. Prasad, L. Kennedy and E. Ruckenstein, Catal. Rev. Sci. Eng., 26, 1 (1984).

4) H. Sadamori and A. Chikazawa, J. Fuel Soc. Jpn., 67, 834 (1988).
5) J. D. Birchall, Trans. J. Br. Ceram. Soc., 82, 143-45 (1983).

6) M. Sekine, S. Katayama and M. Mitomo, J. Non-Cryst. Solids, 134, 199-207 (1991).

7) Y. Mizushima and M. Hori, J. Mater. Res., to be published (1993).

8) R. B. Anderson, K. C. Klein, J. J. Feenan and L. J. E. Hofer, Ind. Eng. Chem., 53, 809 (1961).

9) S. Hayashi and S. Yamada, GTSJ, 18-70, 17 (1990).

10) L. B. Pankratz, "Thermodynamic Properties of Elements and Oxides", U. S. Bureau of Mines Bulletin (1982) p. 672.

11) P. Scherrer, Göttingen Nachrichten, 2, 98 (1918).

12) S. R. Sashital, J. B. Cohen, R. L. Burwell, Jr. and J. B. Butt, J. Catal., 50, 479 (1977).

13) M. M. Dubinin, Adv. Colloid Inter. Sci., 2, 217 (1968).

14) IUPAC, Pure Appl. Chem., 67, 603 (1985).

15) T. Inui, Seramikkusu, 15, 324 (1980).

16) T. Inui, Chem. Eng. Jpn., 46, 413 (1982).

17) T. Inui, T. Sezume, K. Miyaji and Y. Takegami, J. Chem. Soc. Chem. Commun., 873 (1979). 